\title{
Kronik Hepatit B Hastalarında Non-invaziv Fibrozis Skorlama Yöntemlerinin Karaciğger Biyopsisi ile Karşılaştırılması
}

\section{Comparison of Non-invasive Fibrosis Scoring Methods with Liver Biopsy in Chronic Hepatitis B Patients}

\author{
Uğur KESIMAL, Şenay ÖZTÜRK DURMAZ
}

Yazışma Adresi

Correspondence Address

\section{Uğur KESIMALL}

Radyoloji Uzmanı

Kepez Devlet Hastanesi, Türkiye

E-posta:

ugur_kesimal@hotmail.com

Geliş tarihi \Received : 22.06 .2020 Kabul tarihi \ Accepted : 08.08.2020 Elektronik yaymn tarihi $\quad: 12.07 .2021$ Online published

Bu makaleye yapilacak atıf: Cite this article as:

Uğur Kesimal, Şenay Öztürk Durmaz. Kronik hepatit B hastalarında noninvaziv fibrozis skorlama yöntemlerinin karaciğer biyopsisi ile karşılaştırılması. Akd Tip D 2021; 7(2):283-288

Uğur KESIMAL ORCID ID: 0000-0002-7994-5482 Şenay ÖZTÜRK DURMAZ ORCID ID: 0000-0002-5260-2682
${ }^{1}$ Radyoloji Uzmanı, Kepez Devlet Hastanesi

${ }^{2}$ Enfeksiyon Hastalıkları ve Klinik Mikrobiyoloji Uzmanı, Kepez Devlet Hastanesi
ÖZ

Amaç: Son yıllarda kronik hepatit B’li (KHB) hastalarda fibrozisi değerlendirmek amacıyla noninvaziv tanı yöntemleri üzerinde pek çok çalışma yapılmıştır. Ancak halen karaciğer biyopsisi altın standart olarak kabul edilmektedir. Bu çalışmada KHB hastalarının biyopsi sonuçlarını ve non-invaziv fibrozis skorlama bulgularını karşılaştırmayı ve bunların ışığında tedaviye başlama açısından biyopsiyi değerlendirmeyi amaçladık.

Gereç ve Yöntemler: Hastanemiz enfeksiyon hastalıkları polikliniğinde Nisan 2017-Nisan 2019 tarihleri arasında kronik hepatit B nedeniyle takip edilen ve girişimsel radyoloji ünitesinde perkütan karaciğer biyopsisi yapılan 20 hasta çalışma kapsamına alındı. Hastaların, demografik özellikleri, alanin aminotransferaz, aspartat aminotransferaz, HBV-DNA düzeyleri, trombosit sayıları incelendi. APRI (AST to Platelet Ratio Index) ve FIB-4 (Fibrosis-4) değerleri hesaplandı.

Bulgular: Hastalarm ortalama fibrozis skoru 2 $\pm 0,67$, ortalama histolojik aktivite skoru (HAI) $6,79 \pm 2,49$, ortalama trombosit sayıları 235,35 $\pm 54,8410^{3} / \mu \mathrm{L}$ olarak bulundu. APRI değerinin

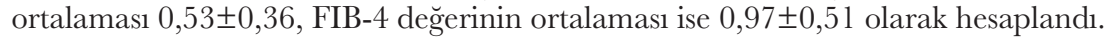

Yapılan istatistiksel analizde HAI - APRI, HAİ - FIB-4, fibrozis skoru - APRI, fibrozis skoru - FIB-4 arasında anlamlı korelasyon saptanmadı (P değerleri sırasıyla 0,473, 0,595, 0,078, 0,718).

Sonuç: Bizim çalışmamızda APRI ve FIB-4 değerleri açısından yapılan istatistiksel değerlendirmede fibrozis derecesi ile korelasyon saptanamamışır. Bunun vaka sayımızın az olmasından kaynaklandığını düşünüyoruz. Verilerimizi detaylı olarak sunduğumuz bu çalışmamızın meta analizlere katkı sunacağı kanaatindeyiz.

Anahtar Sözcükler: APRI, FIB-4, Karaciğer biyopsisi, Kronik hepatit B, Non-invaziv fibrozis skorlama

\begin{abstract}
Objective: In recent years, many studies have been conducted on non-invasive diagnostic methods to evaluate fibrosis in patients with chronic hepatitis $\mathrm{B}(\mathrm{CHB})$. However, liver biopsy is still considered the gold standard. In this study, we aimed to present the biopsy results and non-invasive fibrosis scoring findings of $\mathrm{CHB}$ patients and to determine biopsy in terms of starting treatment.

Material and Methods: Twenty patients who were followed up in our hospital for infectious diseases outpatient clinic between April 2017 and April 2019 due to CHB and who underwent percutaneous liver biopsy in the interventional radiology unit were included in the study. Demographic features, alanine aminotransferase, aspartate aminotransferase, HBV-DNA levels, platelet counts were examined. APRI (AST to Platelet Ratio Index) and FIB-4 (Fibrosis-4) values were calculated.

Results: The mean fibrosis score of the patients was $2 \pm 0.67$, the average histological activity score (HAI) was 6.79 \pm 2.49 , and the mean platelet counts were $235.35 \pm 54.8410^{3} / \mu \mathrm{L}$. The average of APRI (AST to Platelet Ratio Index) value was calculated as $0.53 \pm 0.36$ and the average of FIB-4 (Fibrosis- 4 ) value was calculated as $0.97 \pm 0.51$. In statistical analysis, there was no significant correlation between HAI - APRI, HAI - FIB-4, fibrosis score - APRI, fibrosis score - FIB-4 (P values 0.473, 0.595, 0.078, 0.718 , respectively).
\end{abstract}


Kesimal U. ve Öztürk Durmaz Ş.

Conclusion: In our study, no correlation with the degree of fibrosis was detected in the statistical evaluation in terms of APRI and FIB-4 values. We think this is due to the small number of our cases. We believe that this study, in which we present our data in detail, will contribute to meta-analysis.

Keywords: APRI, Chronic hepatitis B, FIB-4, Liver biopsy, Non-invasive fibrosis scoring

\section{GİRIŞ}

Son yllarda kronik hepatit B'li (KHB) hastalarda fibrozisi değerlendirmek amacıyla non-invaziv tanı yöntemleri üzerinde pek çok çalışma yapılmış olmasına rağmen halen karaciğer biyopsisi altın standart olarak kabul edilmektedir. Genellikle biyopsi sonuçlarına göre başlanan mevcut tedavilerle yapılan KHB tedavisi sayesinde virüs eradikasyonu tam olarak sağlanamamasına rağmen siroz ve hepatoselüler kanser gelişimi büyük ölçüde azalmaktadır. Bu nedenle erken dönemde fibrozisin saptanması ve antiviral tedavi başlanması hastalığın seyrini değiştirebilir (1).

KHB hastalarında HBV-DNA düzeyi, serum alanin-amino-transferaz (ALT) düzeyi ve karaciğer hastalığının şiddeti (karaciğer biyopsisi veya non-invaziv yöntemle) saptanarak tedavi belirlenir (2). Ancak hastaların HBeAg durumu tedavi endikasyonlarını değiştirmez. Karaciğer biyopsisi genellikle güvenli ve basit bir yöntem olarak kabul edilmesine karşın invaziv olması, komplikasyon gelişebilme riski, hastanede yatış gerektirmesi, örnekleme hataları, tüm karaciğer dokusu yerine sadece örnek alınan yerdeki hasar hakkında bilgi vermesi, değerlendirmeyi yapan kişiye ait farklı sonuçların rapor edilmesi, tekrarının zorluğu ve maliyetinin fazla olması, biyopsiden farklı olarak non-invaziv testler geliştirme arayışına sebep olmuştur (3-7). Her ne kadar karaciğerin fibrozis ve nekroinflamasyonun değerlendirilmesinde biyopsi altın standart ise de; biyopsinin invaziv bir işlem olması, komplikasyon gelişebilmesi, histolojik değerlendirmedeki zorluk ve farklılıklar gibi nedenlerden dolayı alternatif tanı ve değerlendirmelerin geliştirilmesi ihtiyacı doğmuştur. Bu amaçla periferik kan örnekleri ve radyolojik yöntemlerden yararlanılmıştır. Bu kullanılan parametrelerin hiçbiri biyopsinin yerini tutmamakla birlikte sensitivite ve spesifisiteleri farklllık gösterir. European Association for the Study of the Liver (EASL) 2017 viral hepatit tedavi rehberinde HBV DNA düzeyi 2000 IU $\backslash \mathrm{mL}$, ALT seviyeleri normal seyreden ve biyopsi olmayı reddeden hastaların tedavi durumuna karar verebilmek için non-invaziv fibröz testlerinin kullanılabileceğini rapor etmiştir (18). Karaciğer biyopsisi olmayan hastalarda biyopsi yerine kullanılabilecek non-invaziv testler mevcut olup $(19,20)$, hastanın ALT, platelet ve HBV DNA değerlerini bilerek hastaların yarısında karaciğer histolojisinin tahmin edilebileceği bildirilmiştir (19).

- (AST/ALT oranı); Siroz gelişmeden önce hepatitlerde AST'nin ALT'ye oranı genellikle birin altında iken siroz geliştikten sonra AST/ALT oranı birin üstüne çıkar (Alkole bağlı karaciğer hastalığı ve Wilson hastalı̆gı dışında).

- APRI (AST to Platelet Ratio Index); (AST'nin trombosit sayımına oranı); AST değerinin laboratuvardaki AST üst sınırına bölünmesi ve trombosit sayımından yararlanılarak hesaplanır. APRI skoru ile yapılan çalışmalarda genelde APRI skorunun 0,5'in altında olan grupta belirgin fibrozis yok saptanırken 1,5 değerinin üzerinde olan grupta belirgin fibrozis olabileceği belirtilmiştir.

- $\quad$ FIB-4 (Fibrosis-4); İlk olarak HIV ve HCV enfeksiyonu beraberliğinde yapılan APRICOT çalışması (AIDS Pegasys Ribavirin International Coinfection Trial) verilerinden yola çıkarılarak oluşturulmuş bir formüldür.

Bu çalışmada yeni açlan bir devlet hastanesindeki KHB hastalarının biyopsi sonuçlarını ve non-invaziv fibrozis skorlama bulgularını karşılaştırmayı ve bunların ışığında tedaviye başlama açısından biyopsiyi değerlendirmeyi amaçladık.

\section{GEREÇ VE YÖNTEM}

Çalışmamız Sağlık Bilimleri Üniversitesi Antalya Eğitim ve Araştırma Hastanesi Klinik Araştırmalar Etik Kurulu tarafindan onaylanmıştır (Karar no: 14/28, 30/05/2019). Çalışma 1964 Helsinki Bildirisi'nde belirtilen etik standartlarına göre yapıldı. Çalışmamızda araştırma ve yayın etĭgine uyulmuştur. Nisan 2017-Nisan 2019 tarihleri arasında hastanemiz enfeksiyon hastalıkları polikliniğinde hepatit B nedeniyle takip edilen ve girişimsel radyoloji ünitesinde perkütan karaciğer biyopsisi yapılan 20 hepatit B hastası çalışma kapsamına alındı. Tüm hastalardan biyopsi öncesinde aydınlatılmış onam alındı. Tüm biyopsiler aynı radyoloji uzmanı tarafindan yapıldı (U.K.). Biyopsi öncesi tüm hastalarda hemogram ve INR sonuçları değerlendirildi, hastalar antikoagülan ve antiagregan kullanımı açısından sorguland. Tüm hastalarda işlem altı saat açlık sonrası uygulanmış olup hastalara işlemden iki saat önce başlanılarak saatte $70 \mathrm{ml}$ serum fizyolojik infüzyonu intravenöz olarak uygulandı. Karaciğer biyopsileri girişimsel radyoloji ünitesinde ultrasonografi (ACUSON S 3000, Siemens Healthcare, Erlangen, Germany) eşliğinde konveks transdüser kullanılarak yapıldı. Tüm biyopsiler karaciğer sağ lobundan $16 \mathrm{G}$ tam otomatik kesici iğne (ESTACORE, Geotek Medikal, Ankara, Türkiye) aseptik koşullarda serbest el tekniği ile yapıldı. Yeterli materyal elde edilebilmesi için her hastada 
iki sefer biyopsi alındı. Hastalar en az altı saat hospitalize edildi ve biyopsiden yaklaşı dört saat sonra komplikasyonlar açısından kontrol ultrasonografileri aynı radyoloji uzmanı tarafindan yapıldı. Daha önce tedavi almış KHB hastaları çalışmaya dahil edilmedi. Biyopsi yapılan hastaların, demografik özellikleri, alanin aminotransferaz, aspartat aminotransferaz (AST), HBV-DNA düzeyleri, trombosit sayıları, bilirubin, albümin ve AFP değerleri incelendi. Biyopsi materyallerinde altı ve daha fazla portal alan içeren numuneler yeterli olarak kabul edildi. Karaciğer biyopsilerinin değerlendirilmesinde ISHAK skorlama sistemi kullanıldı. Histolojik aktivite indeksi (HAI), fibrozis derecesi patoloji raporlarından tarandi. Fibrozis skoru 0-1 olanlar düşük, 2 ve üzeri fibrozis skoruna sahip olanlar belirgin fibrozis olarak değerlendirildi $(8,9)$. Tedaviye başlanma durumları retrospektif olarak elektronik hasta dosyalarından ve epikrizler taranarak elde edildi. APRI ve FIB-4'ün nasıl hesaplandığına ait formüller sırasıyla Şekil 1 ve 2'de gösterilmiştir.

İstatistiksel analiz SPSS paket programı kullanılarak yapildı ("Statistical Package for Social Sciences", versiyon 15; SPSS Inc, Şikago, IL). Sürekli değişkenlerin normal dağılıma uygunluğunun değerlendirmesi için Shapiro-Wilk testi kullanıldı. Tanımlayıcı istatistikler ortalama, standart sapma, frekans ve yüzdelik olarak ifade edildi. İstatistiksel analizde Spearman'ın siralama korelasyon katsayısı ile veriler arasındaki korelasyon değerlendirildi. P 0,05'ten düşük bir değerde ise anlamlı kabul edildi.

\section{BULGULAR}

Çalışmamızda biyopsi yapılan 10'u erkek, 10'u kadın toplam 20 hasta mevcuttu. Ortalama yaş 38,35 $\pm 13,5$ yll olarak hesapland. Dokuz hastada ALT normalden yüksek olup (referans üst sinır $35 \mathrm{U} / \mathrm{L}$ değerin üzerinde), ortalama ALT

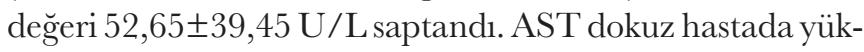
sek (referans üst sınır $34 \mathrm{U} / \mathrm{L}$ değerin üzerinde) saptanmış

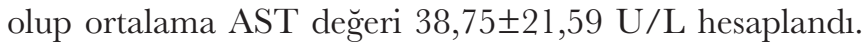
AST-ALT yüksekliği saptananların altısı HBeAg pozitifti. Çalışmaya alınan hastalarda hepatit delta (HDV) ve hepatit $\mathrm{C}(\mathrm{HCV})$ birlikteliği yoktu. Hastaların hiçbirinde AFP yüksekliği saptanmadı. Fizik muayenede spider anjiomlar, telenjiektazi izlenmedi ayrıca hipoalbuminemi gibi siroz belirteçlerine rastlanmadı. Tüm hastalarda ultrasonografik değerlendirmede hafif ve orta düzey arasında parankim heterojenitesi dışında karaciğerde fokal lezyon, varis ya da asit bulgusu saptanmadı. Demografik ve laboratuvar bulguları Tablo I'de özetlenmiştir.

Hastaların birinde biyopsi materyali yetersiz olarak geldi. $\mathrm{Bu}$ nedenle geriye kalan 19 hastanın biyopsi sonuçları değerlendirildi. ISHAK fibrozis skoru (F): 11 hastada iki, dört hastada üç ve dört hastada bir olarak raporlanmıştı. Hastaların ortalama fibrozis skoru $2 \pm 0,67$, ortalama HAI $6,79 \pm 2,49$, ortalama trombosit sayları $235,35 \pm 54,8410^{3}$ / $\mu \mathrm{L}$ olarak bulundu. Hastaların hiçbirinde trombositopeni saptanmadı. APRI değerinin ortalaması 0,53 $\pm 0,36$, FIB-4 değerinin ortalaması ise $0,97 \pm 0,51$ olarak hesaplandı.
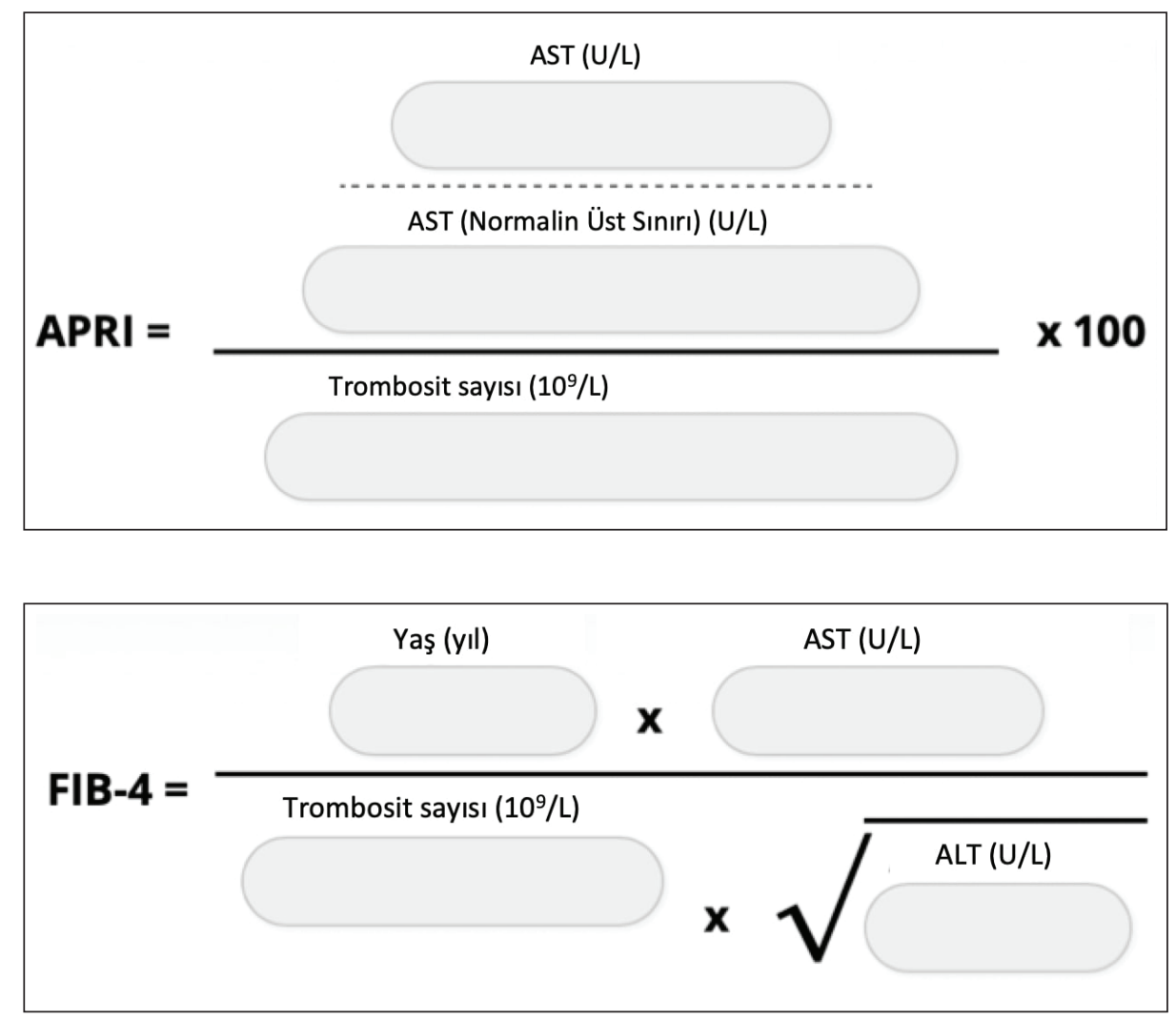

Şekil 1: APRI (AST to Platelet Ratio Index) formülü.

Şekil 2: FIB-4 (Fibrosis-4) formülü. 
Tablo I: Hastaların demografik özellikleri ve laboratuvar sonuçları.

\begin{tabular}{lcc}
\hline Özellik & Ortalama & Minimum - maksimum \\
\hline Yaş (yl $)$ & 38,35 & $19-72$ \\
\hline $\mathrm{ALT}^{*}(\mathrm{U} / \mathrm{L})$ & 52,65 & $12-140$ \\
\hline $\mathrm{AST}^{\dagger}(\mathrm{U} / \mathrm{L})$ & 38,75 & $26-92$ \\
\hline $\mathrm{HBV} \mathrm{DNA}(\mathrm{IU} / \mathrm{mL})$ & $29,79 \times 10^{6}$ & $10,4 \times 10^{2}-20,34 \times 10^{7}$ \\
\hline $\mathrm{HAI}^{*}$ & 6,79 & $4-14$ \\
\hline Fibrozis skoru & 2,00 & $1-3$ \\
\hline Trombosit sayıs! $\left(10^{3} / \mu \mathrm{L}\right)$ & 235,35 & $140-350$ \\
\hline APRI $^{\S}$ & 0,53 & $0,13-1,5$ \\
\hline FIB-4 & 0,97 & $0,35-2,10$ \\
\hline
\end{tabular}

* alanin-amino-transferaz, † aspartat aminotransferaz, ‡ histolojik aktivite indeksi, § "AST to Platelet Ratio Index", | | "Fibrosis-4”

Yapılan istatistiksel analizde HAI - APRI, HAI - FIB-4, fibrozis skoru - APRI, fibrozis skoru - FIB-4 arasinda anlaml korelasyon saptanmadı (P değerleri sirasıyla 0,473, 0,595, $0,078,0,718)$.

Biyopsi sonrası hastalar en sık geçici sağ omuza vuran ağrıdan $(\mathrm{n}=2 \% 10)$ şikayetçiydiler. Ağrı şikayeti olan tüm hastalar non-steroid antiinflamatuvar ilaçlarla tedaviye yanıt verdi. Hiçbir hastada kanama, safra kaçağı, pnömotoraks veya intestinal perforasyon gibi majör bir komplikasyon gözlenmedi.

Biyopsi materyali yetersiz gelen bir hasta hariç diğer hastaların tamamına Sağlık Uygulama Tebliğine (SUT) uygun olarak antiviral tedavi başlandı (ikisine entekavir, 17'sine ise tenofovir disoproksil fumarat).

\section{TARTIŞMA}

Ülkemizde mevcut olan Sağlıkta Uygulama Tebliği (SUT) kriterlerine göre Ishak fibrozis skoru $\geq 2$ ve/veya HAİ skoru $\geq 6$ olan hastalar kronik hepatit kabul edilerek, tedavi başlanması uygun bulunmakta ve bu hastaların ilaç ödemeleri devlet tarafindan karşılanmaktadır (10). Bizim çalışmamızda toplam 15 hastanın fibrozis skoru 2 ve üzerinde saptandı. Bir hastada numune yetersizliği nedeniyle skorlama yapılamamıştı. Dört hastada ise fibrozis skoru 1 olmasına karşın HAI 6 ve üzerinde olduğu için tedavi başlandı. Toplamda 19 hastaya tedavi planland.

HBeAg pozitif HBV DNA değerleri yüksek ve ALT değerleri normal seyreden hastalar 30 yaşına kadar immüntoleran kabul edilip aile öyküsü de yoksa tedavi başlanmayabilir (10). Bizim çalışmamızda tedavi başlanan 19 hastanın altısı HBeAg pozitifti ve bunların da üçü 30 yaş altında ve erkek hastalardı. Bu üç hastanın ALT seviyeleri yüksekti ailesinde kronik hepatit B ve buna bağlı karaciğer sirozu tanısı alan kişiler vardı. Bu hastalar immunoaktif kategoride değerlendirildi.

Karaciğer biyopsisinde değerlendirme için yeterli biyopsi materyali alınamaması uygulayıcının ve merkezin deneyi- miyle ilgilidir. Bu konuda literatürde değişik oranlar belirtilmektedir. Tuna ve ark.'’n 2011 yllında yaptığı çalışmada yetersiz numune alma oranını \%5,4 olarak bulunmuştur (11). Solak-Grassie ve ark. 2017 yılında 25 olguda karaciğer biyopsisini değerlendirdikleri çalı̧̧malarında 4 hastanın sonuçlarının $(\% 16)$ yetersiz biyopsi materyali olarak raporlandığını belirtmişlerdir (11). Bizim çalışmamızda yapılan 20 biyopsiden sadece birinde (\%5) biyopsi materyali yetersiz olarak raporlanmış olup kabul edilebilir sınırlarda olarak değerlendirilmiştir.

Karaciğer biyopsisinin ultrasonografi eşliğinde yapılması ve tecrübeli bir hekim tarafindan gerçekleştirilmesi komplikasyon riskini azaltır $(11,12)$.

Perkütan karaciğer biyopsilerinde geçici ağrı, bulantı minor komplikasyon olarak değerlendirilirken hemoraji, hemobiliya, biliyer kolik, pnömotoraks, peritonit ve ölüm major komplikasyonlar olarak değerlendirilir $(13,14)$. Karaciğer biyopsisi sonrası mortalite oranları $\% 0,01$ ve komplikasyon oranlarının \%0,06 ile 0,32 arasında değiştiği bildirilmektedir (15). Büyükkaya ve ark.'nın 2013 yılında 120 hastada ultrason eşliğinde yaptıkları perkütan karaciğer biyopsilerin $\% 5$ 'inde ağrı kesicilere yanıt veren geçici ağrı saptamışlar ve $1(\% 0,83)$ hastada majör komplikasyon geliştiğini rapor etmişlerdir (16). Arıbaş ve ark. da perkütan tru-cut iğne ile yaptıkları 160 biyopsiyi değerlendirdikleri çalışmada en sık şikayetin ağrı kesicilere yanıt veren ağrı olduğunu bildirmişlerdir (17). Biyopsi sonrası en sık gözlemlenen komplikasyon ağrıdır. Bizim çalışmamızda biyopsi yapılan hastaların 2'sinde (\%10) ağrı mevcuttu ve antiinflamatuar ilaçlara yanıt verdi. Yaptığımız biyopsilerde majör bir komplikasyon gözlenmedi.

Yapılan çalışmalarda gösterilmiştir ki; tek başına APRI belirgin fibrozisi dışlamak için yeterince hassas değildir. Bazı kanitlar, kombinasyon halinde çoklu endekslerin (APRI + FibroTest gibi) veya algoritmik bir yaklaşımın kullanılmasının, sadece APRI kullanmaktan daha yüksek tanısal doğrulukla sonuçlanabileceğini öne sürmektedir (21). 
FIB-4'ü değerlendiren çalışmalara bakıldığında ise; 1,45'den daha düşük bir eşik değer kullanıldığında FIB-4 skoru $<1,45$ ise ileri fibrozis için \% 90 negatif prediktif değer tespit edildiği belirtilmiştir (Ishak fibrozis skoru 4-6). Buna karşllık, FIB-4 >3,25 ise ileri fibrozis için \% 97 özgüllüğe ve \% 65’lik pozitif bir öngörü değeri ortaya konmuştur. Bu formülün ilk kez doğrulandığı hasta kohortunda, en az $\% 70$ hastanın değeri < 1,45 veya $>3,25$ saptanmış olup yazarlar, bu bireylerde potansiyel olarak \% 86 doğrulukla karaciğer biyopsisinden kaçınılabileceğini savunmuşlardır (22). Köksal ve ark.'nın 2018 yllında 182 kronik hepatit C'li hastada yaptı̆̆ çok merkezli çalışmada non-invaziv testlerin en az ikisinin birlikte yapılması gerektiği (23) ve bunu destekleyen bir çok çalışmada da karaciğer fibrozis değeri ne kadar yüksekse non-invaziv testlerin de güvenilirliğinin o kadar arttığı sonucuna ulaşılmıştır (24). Ayrıca yapılan çalışmalarda karaciğer fonksiyonlarının kritik rol aldığı HELLP (hemolysis, elevated liver enzyme levels, low platelet counts) sendromu gibi önemli klinik tablolarda da APRI gibi non-invaziv testlerin, tanıy sadece AST'ye oranla daha güçlü desteklediği ortaya konmuştur (24). Bizim çalışmamızda APRI ve FIB-4 değerleri açısından yapılan istatistiksel değerlendirmede fibrozis derecesi ile korelasyon saptanamamışır. Bunun vaka sayımızın az olmasından kaynaklandığını düşünüyoruz.

Çalışmamızın en önemli kısıtlılığı vaka sayısının az olmasıydı. Ancak neticede non-invaziv yöntemler dışındaki bulgularımız literatür ile benzer olarak tespit edilmiştir.

Biyopsinin başarısız ya da mümkün olmadığı durumların olması, olası yan etkilerin hastanın konforu ve hayati tehli-

\section{KAYNAKLAR}

1. Schweitzer A, Horn J, Mikolajczyk RT, Krause G, Ott JJ. Estimations of worldwide prevalence of chronic hepatitis B virus infection: a systematic review of data published between 1965 and 2013. Lancet 2015; 386(1003): 154655.

2. Papatheodoridis G, Zoulim F, Tacke F. EASL 2017 Clinical Practice Guidelines on the management of hepatitis B virus infection. J Hepatol 2017 67(2) 370-98.

3. Bravo A, Sheth SG, Chopra S. Liver biopsy. N Eng J Med 2001; 344: 495-500.

4. Crespo J. The art of predicting fibrosis in hepatitis C. Rev Esp Enferm Dig 2006; 98: 153-60.

5. Mardini H, Record C. Detection of assessment and monitoring of hepatic fibrosis: Biochemistry or biopsy? Ann Clin Biochem 2005; 42: 441-7. kesi açısından önemli olabileceği nedeniyle bu non-invaziv tekniklere ihtiyaç kaçınılmazdır.

Sonuç olarak biyopsinin risklerinden kaçınabilmek adına karaciğer fibrozisinin non-invaziv yöntemlerle değerlendirilmesi konusunda daha çok vaka sayısına sahip çok merkezli çalışmalar ve metaanalizler yapılması gerektiği aşikardır. Verilerimizi detayı olarak sunduğumuz bu çalışmamızda vaka sayımızın az olmasına rağmen ülkemiz ölçeğinde yapılacak olan metaanalizlere katkı sunacă̆ı kanaatindeyiz.

Finansman veya Mali Destek: Çalışmada herhangi bir finansman ya da mali destek yoktur.

Çıkar Çatışması: Yazarlar çıkar çatışması belirtmemektedirler.

\section{Yazarların Katkısı:}

Çalısmanın konsepti ve dizaynı: UK, ŞÖD

Verilerin toplanması ve işlenmesi: UK, ŞÖD

Verilerin analizi ve yorumlanması: UK, ŞÖD

Literatür araştırması: UK, ŞÖD

Makalenin yazımı: UK, ŞÖD

Kritik gözden geçirme: UK, ŞÖD

Yayınlanacak versiyonun nihai onayı: UK, ŞÖD

Çalışmamız Sağlık Bilimleri Üniversitesi Antalya Eğitim ve Araştırma Hastanesi Klinik Araştırmalar Etik Kurulu tarafindan onaylanmıştır (Karar no: 14/28, 30/05/2019).

6. Piccinino F, Sagnelli E, Pasquale G, Giusti G. Complications following percutaneous liver biopsy. A multicentre retrospective studyon 68.276 biopsies. J Hepatol 1986; 2: 165-73.

7. Bedossa P, Dargere D, Paradşs V. Sampling variability of liver fibrosis in chronic hepatitis C. Hepatology 2003; 38: 1356-8.

8. Knodell RG, Ishak KG, Black WC, Chen TS, Craig R, Kaplowitz N, Kiernan TW, Wollman J. Formulation and application of a numerical scoring system for assessing histological activity in asymptomatic chronic active hepatitis. Hepatology 1981; 1: 431-5.

9. Desmet VJ, Gerber M, HoofnagleJH, Manns M, Scheurer PJ. Classification of chronic hepatitis: Diagnosis, grading and staging. Hepatology 1994; 19: 1513-20.

10. Solak-Grassie S, Gözütok F, Coşkun B, Dural S, Atakent ŞD. Evaluation of $\mathrm{HBeAg-negative} \mathrm{chronic} \mathrm{hepatitis} \mathrm{B}$ patients who had undergone liver biopsy in accordance with the guidelines. Klimik Derg 2018; 31(1): 37-40. 
11. Tuna N, Yahyaoğlu M, Öztürk G, Öğütlü A, Çalica UA, Durmaz Y, Gözdaş HT, Güçlü E, Karabay O. Liver biopsy experience. Viral Hepatitis Journal 2012; 18(3): 115-9.

12. Erdem H. Karaciğger iğne biyopsisi. Ed: Tabak F, Tosun S. Viral Hepatit 2013. Ankara:Viral Hepatitle Savaşım Derneği, 2013: 13-23.

13. Paulson EK and Nelson RC. Techniques of Percutaneous Tissue Acquisition. In: Textbook of Gastrointestinal Radiology. Ed: Gore RMG, Levine MS. Second edition. W.B. Saunders Company 1219-33.

14. Smith EH. Complications of percutaneous abdominal fine-needle biopsy: a review. Radiology 1991; 178: 253-8.

15. Picciniono F, Sagnelli E, Pasquela G, Giusti G. Complications after percutaneous liver biopsy. J Hepatol 1986; 2: 165-73.

16. Büyükkaya R, Oktay M, Büyükkaya A, Öztürk B, Özel MA, Beşir FH, Yazıcı B. Kronik Viral Hepatitli Hastalarda Ultrasonografi Eşliğinde Kesici İ̆ne İle Yapılan Perkütan Karaciğer Biyopsilerinin Değerlendirilmesi. Abant Med J 2014; 3(2): 112-5.

17. Arıbaş BK, Ünlü DN, Dingil G, Demir P, Özdemir S, Şimşek Z, Üngül Ü, Zaralı AC. Yarı-otomatik 16 Gauge Tru-cut İğne ile Perkütan Karaciğger Biyopsileri. Van Tip Dergisi 2010; 17(3): 69-76.

18. El-Zayadi AR, Badran HM, Saied A, Shawky S, Attia Mel-D, Zalata K. Evaluation of liver biopsy in Egyptian $\mathrm{HBeAg}$-negative chronic hepatitis $\mathrm{B}$ patients at initial presentation: implications for therapy. Am J Gastroenterol 2009; 104(4): 906-11.

19. Gao S, Fan YC, Zhao J, Sun FK, Han J, Zhao ZH, Wang K. A model to predict antiviral treatment in $\mathrm{HBeAg}$ negative chronic hepatitis $\mathrm{B}$ with alanine aminotransferase $\leq 2$ upper limit of normal. Liver Int 2014; 34(7): 229-37.
20. Lurie Y, Webb M, Cytter-Kuint R, Shteingart S, Lederkremer GZ. Non-invasive diagnosis of liver fibrosis and cirrhosis. World J Gastroenterol 2015; 21(41): 11567 83.

21. Chou R, Wasson N. Blood tests to diagnose fibrosis or cirrhosis in patients with chronic hepatitis $\mathrm{C}$ virus infection: a systematic review. Ann Intern Med 2013; 158: 807-20.

22. Sterling RK, Lissen E, Clumeck N, Sola R, Correa MC, Montaner J, S Sulkowski M, Torriani FJ, Dieterich DT, Thomas DL, Messinger D, Nelson M. Development of a simple non-invasive index to predict significant fibrosis patients with HIV/HCV co-infection. Hepatology 2006; 43: 1317-25.

23. Köksal I, Yılmaz G, Parlak M, Demirdal T, Kınıklı S, Candan M, Kaya A, Akhan S, Aydoğdu Ö, Turgut H, Gürbüz Y, Dağlı Ö, Gökal AA, Güner R, Kuruüzüm Z, Tarakçı H, Beslen N, Erdoğan S, Özdener F. Diagnostic value of combined serum biomarkers for the evaluation of liver fibrosis in chronic hepatitis $\mathrm{C}$ infection: A multicenter, noninterventional, observational study. Turk J Gastroenterol 2018; 29(4): 464-72.

24. Yilmaz Y, Yonal O, Kurt R, Bayrak M, Aktas B, Ozdogan O. Non-invasive assessment of liver fibrosis with the aspartate transaminase to platelet ratio index (APRI): Usefulness in patients with chronic liver disease APRI in chronic liver disease. Hepat Mon 2011; 11(2): 103-6.

25. Şaşmaz MI, Ayvaz MA, Dülger AC, Kuday-Kaykısız EK, Güven R. Aspartate-aminotransferase to platelet ratio index score for predicting HELLP syndrome. Am J Emerg Med 2020; 38(3): 459-62. 